\title{
DINAMISASI PENORMAAN HUKUM ISLAM
}

\author{
Abd. Shomad \\ Fakultas Hukum \\ Universitas Airlangga
}

Abstrak

Dinamisasi penamaan dalam hukum Islam tergantung perbedaan penerapan dan perkembangan untuk Islam. Hal ini juga dipengaruhi oleh kondisi perkembangan hukum Islam di berbagai Negara.

Hukum Islam merupakan hokum yang hidup yang inherion dalam kehidupan umat Islam. Oleh karena itu Norma Islam tidak lagi dirasakan sebagai norma yang dipaksakan dari luar oleh umatnya. Perkembangan hukum Islam di Indonesia, ditandai perbedaan seru yang melakukan dua teori Receptio in compten dan teori receptive.

Kata Kunci: Dinamisasi, Penormaan, Hukum Islam

\section{Abstract}

Dynamic naming dependent differences in Islamic law for the implementation and development of Islam. It is also influenced by the development of Islamic law in various countries.

Islamic law is the law of life that inherion in the lives of Muslims. Therefore the Islamic norms are no longer perceived as the norm imposed from the outside by his people. The development of Islamic law in Indonesia, marked differences which make the two theories exciting receptio in compten and receptive theory.

Keywords : dynamic, norm, Islamic Law

\section{PENDAHULUAN}

Pengkajian Hukum Islam dilingkungan akademis semakin menarik seiring dengan problematika yang muncul silih berganti muncul baik dalam bidang ideologi, politik, sosial budaya, hankam, ekonomi, HAM dan teknologi yang terkadang membutuhkan suatu pemecahan dari aspek hukum Islam. Dalam tataran ideologi perdebatan di kalangan pemerhati Hukum Islam muncul tatkala pencanangan asas tunggal oleh Presiden Soeharto, Presiden wanita, parpol berlabel agama dan sederet masalah politik, serta usulan amandemen pasal 29 UUD tidak terlewatkan perdebatannya di antara pemerhati Hukum Islam. Perdebatan di arena politik muncul seiring dengan perkembangan Hukum Islam. (Abdul Qahir Al-Bagdadi, 1973).

Hukum Islam datang di bumi Indonesia (Nusantara) bersamaan dengan datangnya orang Islam di bumi Nusantara. (Mohammad Aud Ali,1984:7) Dari komunitas Islam yang bertebaran berlanjut dengan muncul kerajaankerajaan Islam dan berakibat munculnya badan peradilan yang berdasarkan Hukum Islam yang diantaranya memperoleh bentuk ketatanegaraan dalam masa kesultanan Islam itu. Pada masa penjajahan Belanda, pemeritah Hindia 
Belanda mengakui secara formal keberadaan Peradilan Agama dengan keputusan Raja Belanda Nomor 24 tertanggal 19 Januari 1882 yang dimuat dalam Stb. 1881 Nomor 152 yang dikenal dengan Bepalingen betreffende de Priesterradden op Java en Madoera berlaku sejak 1 Agustus 1882 yang termuat dalam Stb. 1882 Nomor 153, yang kemudian dirubah dengan Stb. 1937 Nomor 116. Yang kemudian berkembang sampai dengan diundangkannya Undangundang Nomor 3 tahun 2006 tentang Perubahan atas Undang-undang Nomor 7 Tahun 1989 tentang Peradilan Agama Di lingkungan badan peradilan khusus dengan kewenangan mengadili perkara perdata tertentu dan untuk golongan penduduk tertentu itulah pemikiran Hukum Islam yang berkembang pesat di lingkungan akademis menjadi tempat apilikasi yang utama. Hukum materiil yang diterapkan di Indonesia khususnya melalui pengadilan agama tidak selamanya sama dengan apa yang diajarkan oleh para ahli hukum Islam dalam literatur klasik karena terkadang berpedoman pada hukum positif yang mengaturnya.

Perbedaan penerapan dan pelembagaan Hukum Islam di Indonesia tidak terlepas dari kondisi pelembagaan di berbagai negara. Hukum Islam merupakan hukum yang hidup yang inheren dalam kehidupan umat Islam, maka hukum Islam yang telah menjadi bagian dari kehidupan tidak lagi dirasakan sebagai norma-norma yang dipaksakan dari luar diri mereka. Dengan alasan tersebut, Hukum Islam dilaksanakan dalam Negara yang umat Islam kelompok minortitas sebagai akomodasi politik pemerintah terhadap warganya yang minoritas. Dalam negara di mana umat Islam sebagai mayoritas, hukum Islam dipergunakan untuk memperlancar pelaksanaan kebijaksanaan pemerintah, seperti program KB dan asas tunggal. (Sudirman Tebba,1993:13-14)

Menurut Sudirman Tebba terdapat dua kecendrungan yang menonjol tentang perkembangan Hukum Islam di Asia Tenggara, yakni: Pertama, Hukum Islam telah berubah dan bergeser dari orientasinya yang menekankan pada persoalan ibadah di masa lalu menjadi persoalan muamalah dewasa ini. Kedua, Perkembangan kontemporer bahwa perdebatan hukum itu tidak lagi hanya mengacu kepada madzab yang dipegang selama ini, yakni madzab Syafi'i. Malah perdebatan hukum kadang-kadang tidak mengacu kepada pemikiran dalam terdahulu, tetapi langsung menghadapkan persoalan hukum itu kepada tuntutan masyarakat sekarang. (Sudirman Tebba:1993;16-17)

Perkembangan kontemporer Hukum Islam di Indonesia ialah muncul- 
nya Kompilasi Hukum Islam, Undangundang Pengelolaan Zakat dan Undangundang Haji. Kompi-lasi Hukum Islam melalui Instruksi Presiden Nomor 1 Tahun 1991. Kompi-lasi Hukum Islam sendiri menghasilkan kajian kritis yang telah banyak dilaku-kan baik dikalangan akademis maupun dikalangan umum lainnya. Kehadiran seakan mengobati "rasa rindu"akan ke-hadiran kesatuan pandang akan pelak-sanaan hukum Islam, khususnya di Indonesia.

Di sisi lain dalam era new economy dunia sedang memasuki budaya global dengan kemajuan teknologi informatika. Di satu sisi dan kebangkitan nasionalisme dan spiritual di sisi lain, juga antara lain disemarakkan dengan perkembangan "Ekonomi Islam" yang merupakan hasil serangkaian "reaktualisasi” doktrin Islam tentang masalah ekonomi dalam wajah kekinian. Permasalahan yang mengedepan ialah bagaimanakah dinamisasi penormaan Hukum Islam?

\section{Karakteristik Dinamis Hukum}

Kata "Islam" adalah masdar dari kata kerja "aslama; salima; salama" (Syaidus Syahar: 1986; 8-9) menurut H.A.R. Gibb berarti "submitting (oneself or ones person to good). (H.A.R. Gibb, Mohammedanisn, The New American Library, New York, 1955, hal. 11) Mukti Ali memberikan beberapa ciri-ciri Islam, yakni : (1)Agama yang sederhana, ajarannya mudah diterima. Kewajibankewajiban yang ditetapkan seukuran dengan kemampuan orang normal. Islam tidak menyuruh orang mengerjakan perbuatan-perbuatan yang melampaui orang normal. (2)Islam tidak menyuruh orang untuk mempercayai sesuatu yang bertentangan dengan akal. Tidak berarti bahwa semua ajaran Islam itu dapat dijangkau oleh akal, tapi tidak bertentangan dengan akal. (3)Islam adalah cocok dengan kodrat dan fitrah manusia. (4)Ajaran Islam adalah seimbang antara kepentingan individu dan masyarakat; antara ratio dan emosi; antara keadilan dan kasih sayang; seimbang antara rohani dan jasmani. (5)Islam menunjukkan jalan menuju kebahagiaan. (A. Mukti Ali,1970:15-17)

Dengan demikian Islam merupakan suatu ajaran yang berisi tuntutan yang harus dilaksanakan guna mencapai kebahagiaan hidup di dunia dari keselamatan di akhirat. Pada garis besarnya agama Islam memberikan pedoman hidup dalam segala aspek, secara sistematis meliputi 3 (tiga) aspek besar, yakni : Aqidah, Syari'ah, dan Akhlaq Islam Aqidah adalah aspek fundamental dalam Islam, yang menjadi titik tolak permulaan untuk menjadi muslim (orang Islam) (Nasruddin Razak: 1972;122.) Aqidah Islam ialah hal-hal yang 
diyakini oleh orang-orang Islam, artinya mereka menetapkan atas kebenarannya. (Sahilun A. Nasir: 1980;13)

Sayyid Sabiq berpendapat bahwa pengertian aqidah itu tersusun dari enam perkara, yaitu : (Sayyid Sabiq: 1986:17.) (1)Ma'rifat kepada Allah, ma'rifat dengan nama-Nya yang mulia dan sifatsifatNya yang Tinggi. (2)Ma'rifat dengan alam yang ada dibalik alam semesta ini, yakni alam yang tidak dapat dilihat. (3)Ma'rifat dengan kitab-kitab Allah, yang diturunkan olehNya untuk para rasul. (4)Ma'rifat dengan nabi-nabi serta rasul-rasul Allah, yang dipilih oleh-Nya untuk menjadi pembimbing ke arah petunjuk yang benar. (5)Ma'rifat dengan hari akhir dan peristiwa-peristiwa yang terjadi saat itu, seperti : hidup sesudah mati, akan memperoleh balasan pahala dan siksa, surga dan neraka. (6)Ma'rifat kepada takdir (qodlo dan qodar) yang diatas landasannya itulah berjalan peraturan segala yang ada di dalam alam semesta ini, baik penciptaan dan pengaturannya.

Bidang aqidah merupakan bidang yang fundamental yang melandasi segala tindakan manusia dalam hidupnya sebagai pemeluk agama Islam. Syari'at istilah syari'at Islam, memberi arti hidup yang harus dilalui atau perundangan yang harus dipatuhi oleh seorang Islam, (Nasruddin Razak:1972;249.) merupa- kan suatu sistem norma yang mengatur hubungan manusia dengan Tuhan (Ibadah), sesama manusia dan lingkungannya (muamalah). Ibadah dalam Islam menyangkut hubungan antara manusia dengan Allah, dan hubungan manusia dengan sesamanya. Pengaturan hubungan manusia dengan Allah merupakan ibadah yang bersifat murni, yakni perbuatan khusus yang isinya ibadah, misalnya : thaharah, shalat, zakat, puasa dan haji, yang dikenal sebagai ibadah mahdah. Segala perbuatan manusia di luar ibadah yang semata-mata untuk mencari keridlaan Allah disebut juga ibadah . Dengan demikian seluruh aktifitas hidup yang tidak melanggar syariah dan dilaksanakan sebagai kewajiban hidup merupakan ibadah.

Akhlaq Islam adalah suatu sifat yang tertanam dalam jiwa yang dari padanya timbul perbuatan-perbuatan yang mudah, dengan tidak memerlukan pertimbangan (lebih dulu). (Humaidi Tatapangarsa:1979; 9) Bidang akhlaq yang dapat dinyatakan sebagai hasil iman dan ibadah mempunyai kedudukan amat penting dalam Islam, aspek ini dikaji dalam Ilmu Akhlaq.Aqidah adalah fundamen dalam kehidupan Islam, sedang ibadah adalah manifestasi dari pada iman itu (aqidah). Kualitas iman seseorang dibuktikan dalam pelaksanaan ibadahnya kepada Allah dan realisasi 
syariah dalam kehidupannya.

(Nasruddin Razak, op. cit.hal. 182.)

Aqidah atau keimanan lebih dulu harus dimiliki sebelum orang melaksanakan syariah sebagai uraian Syaikh Mahmoud Syaltout menulis : (Syaikh Mahmoud Syaltout: 1967;20-21.)

"Aqidah itu di dalam posisinya menurut Islam adalah pokok yang dibina diatasnya perundang-undangan agama (syariah). Sedang perundang-undangan agama itu sendiri adalah hasil yang dilahirkan oleh kepercayaan tersebut. Maka dengan demikian tidaklah akan terdapat syariat dalam Islam melainkan karena adanya kepercayaan........"

Aqidah adalah dasar yang harus dimiliki sebelum melaksanakan syariah setelah melaksanakan syariah diharapkan memiliki akhlaq yang baik. Dengan akhlaq yang baik dakan sangat bermanfaat bagi lingkungan sekitarnya.

Hukum Islam sebagai sistem hukum yang bersumber dari Dinul Islam merupakan salah satu legal system yang eksis disamping legal system yang lain seperti Romano Germanic (Civil Law), Common Law, (Edgar Bodenheimer, John Bilyev Odleley, Jean C. Love; 1988.) Sosialist Law. (Hukum di Negara sosialis, diulas dalam dalam Rene David and Jhon C. Brierly, Mayor_Legal System in the World Today, Steven \& Sons, London, 1978, p. 143-283.) Steven
Vago menulis bahwa Islamic Law, ......, is not and independent branch of knowledge, law is integral to Islamic religion.(Steven Vago, 1994, p. 12;)

Sebagian suatu sistem hukum dan suatu disiplin ilmu, hukum Islam mempunyai dan mengembangkan istilah-istilahnya sendiri sebagaimana disiplin ilmu yang lain. Dalam studi Hukum Islam , di Indonesia, seringkali dijumpai istilah-istilah: Hukum Islam, disamping istilah syariat Islam, serta beberapa istilah teknis lainnya. Istilah hukum Islam merupakan istilah khas Indonesia, sebagai terjemahan al-fiqh alIslamy atau dalam konteks tertentu dari al-syariah al- Islamy. Istilah ini dalam wacana ahli hokum barat digunakan Islamic Law. Dalam Al Quran maupuan dalam As Sunnah istilah al-hukm alIslam tidak dijumpai, yang digunakan ialah kata syari'at yang dalam penjabaran -nya kemudian lahirlah istilah fiqh. (Ahmad Rofiq, 1998, hal.3)

Untuk mendapatkan gambaran yang jelas mengenai Hukum Islam pelu dipahami dulu pengertian istilah hukum, syariah dan fiqh. Hukum (Hukm), secara harfiah berarti: menetapkan sesuatu. Para ahli dari berbagai disiplin ilmu dalam Islam mengemukakan berbagai pendapat dalam mendefinisikan hukum, dikarenakan perbedaan tujuan. Menurut ahli Ushul Fiqh, yakni Al Baedlowi, 
hukum ialah peraturan Allah mengenai amal perbuatan mukallaf yang mengandung penetapan atau kebolehan memilih. Sedang menurut Syekh Zakariya Al Anshori, hukum ialah titah Allah yang bertalian dengan perbuatan mukallaf dengan tuntutan supaya berbuat atau meninggalkan atau menerangkan kebolehan atau menjadikan sesuatu sebab, syarat, penghalang, penerus atau perusak bagi sesuatu hukum. Terdapat perbedaan pandangan antara ulama ushul figh dengan ulama fiqh tentang definisi hukum terletak pada ulama ushul figh menjadi hukum sebagai nama dari setiap titah Allah, tetapi tidak dinamai hukum oleh ulama fiqh, sebab yang dinamai hukum oleh ulama fiqh ialah akibat dari kandungan titah tersebut. (A.Azis Mashuri, h. 23-24.)

Istilah hukum dalam pengertian yang seluas-luasnya, maka dalam Islam dikenal 3 macam hukum, yakni : (1). Hukum I'tiqadiyah, hukum keimanan, yang berkaitan dengan hal-hal yang harus diyakini atau dipercaya oleh setiap mukallaf, mengenai Allah, MalaikatNya, Kitab-kitab-Nya, para Rasul-Nya dan Hari kemudian, seta Qadla dan Qadar. (2). Hukum Khuluqiyah, Hukum Akhlaq, yang berkaitan dengan perilaku yang harus dimiliki mukallaf(3). Hukum Amaliyah, yakni hukum yang berkaitan dengan perbuatan setiap mukallaf meliputi masalah ucapan,akad (contract) dan pengelolaan harta benda, dan hubungan hukum dengan sesama. (Abdul Wahhab Khallaf, 1985, h. 38.)

Dalam lingkup hukum amaliyah hukum diartikan sebagai titah Allah atau Sunnah Rasul tentang perbuatan manusia mukallaf, baik diperintah atau dilarang ataupun diperbolehkan, serta tentang keadaan tertentu yang menjadi sebab, syarat atau penghalang bagi berlakunya sesuatu. Berdasarkan definisi atau pengertian di atas, maka dapat disimpulkan bahwa yang dinamakan dengan Hukum Islam adalah nama bagi segala perintah Allah dan utusan-Nya yang mengandung perintah, larangan, pilihan, atau menyatakan syarat, sebab, dan halangan untuk suatu perbuatan hukum. Dalam pengertian demikian, maka Hukum Islam dapat dibagi dalam : (1)Hukum Takliefi, yakni hukum yang mengandung tuntutan yang berupa perintah atau larangan; (2)Hukum Takhyieri, yakni hukum yang mengandung keizinan antara mengerjakan atau meninggalkannya.

Dari segi takliefi dan takhyieri perbuatan hukum dapat dibagi dalam lima kategori : wajib, mandub, haram, sunnah atau mandub dan mubah. Ke lima kategori ini dikenal dengan sebutan al ahkamul khomsah (Hazairin, 1990, h.68-72) 
Syari'at,menurut bahasa (etimologi) berarti jalan yang lempang; jalan yang dilalui air terjun; (T.M.Hasbi Ash Shiddieqy, 1985, h. 7) jalan ke sumber air atau tempat orang-orang minum, khususnya pada jalan setapak menuju palung air yang tetap dan diberi tanda jelas terlihat mata, jadi berarti jalan yang jelas kelihatan atau jalan raya untuk diikuti; sumber air atau sumber kehidupan; atau juga jalan yang harus diikuti. (A.A Fyzee;1995:5). Al quran mengguna -kan kata dan syir'ah dan syari'ah dalam arti "din" yakni dalam arti jalan yang telah ditetapkan Tuhan bagi manusia; jalan yang jelas ditunjukkan Tuhan kepada manusia.Pada masa RasulullahNabi Muhammmad SAW - hidup istilah syar'i sebagai bentuk jamak dari kata syari'ah digunakan dalam arti masalahmasalah pokok Islam.(Ahmad Hasan: 1984;7) Imam Abu Hanifah (700-765 M) , mendefinisikan syari'ah sebagai semua yang diajarkan oleh Nabi Muhammad yang bersumber pada wahyu, yakni semua bagian-bagian ajaran Islam. Para ulama memandangnya sebagai definisi yang luas.(Syaidus Sahar:1986; 23-24) Dalam kaitannya dengan “din”, Abu Hanifah menjelaskan bahwa din tidak pernah berubah sedang syari'ah terusmenerus berubah dalam perjalanan sejarah. Din adalah pokok-pokok iman, sedang syari'ah ialah kewajiban yang harus dijalani. Imam Syafi'i (767 - 820 M), mengartikan syari'ah dengan peraturan-peraturan lahir bagi umat Islam yang bersumber pada wahyu dan kesimpulan (deductions) yang dapat ditarik dari wahyu. Peraturan-peraturan lahir ini mengenai cara bagaimana manusia berhubungan dengan Allah dan sesama makhluk., khususnya sesama manusia. Para ulama memandangnya sebagai definisi yang sempit. Imam Syafi'i menggunakan istilah syari'ah dalam pengertian lembaga, lebih jauh lagi, ia menggunakan istilah syar'i dengan pengertian kewajiban-kewajiban yang harus dilaksanakan. Syaikh Mahmout Syaltout mendefinisikan. (Syaikh Mahmuout Syaltout; 1967:19) :

"Syari'ah ialah peraturanperaturan yang diciptakan Allah, atau yang diciptakannya pokok-pokoknya supaya manusia berpegang kepadanya dalam perhubungan dengan Tuhan, dengan saudara sesama muslim, dengan saudaranya sesama manusia, beserta hubungannya dengan alam seluruhnya dan hubungannya dengan kehidupan"

Secara singkat Fyzee mengartikan syariah dengan cannon law of Islam, the totality of Allah commandements.(A.A Fyzee:1986;23-24) Dari uraian histori di atas golongan ulama yang muncul sesudah abad ke III hijriyah telah memakai kata syari'at untuk nama- 
nama hukum fiqh, yang berhubungan dengan perbuatan mukallaf. Atas dasar pemakaian ini, timbul perkataan Islam adalah aqidah dan syari'ah, yang dinamakan atau dimaksud dengan syari'ah adalah arti yang sempit yang berarti qanun.(RMHasbi Ash Shiddieqy;1985: 89)

Kata Fiqh, menurut bahasa atau etimologi berarti: pintar, cerdas (Nasrudin Razak;1972: 258) tahu, dan faham menurut asal mulanya faham terhadap tujuan seorang pembicara dari pembicaraannya; paham sampai mendalam. Istilah fiqh mengalami perkembangan sejak awalnya sampai menjadi istilah yang dikenal saat ini. Semula berarti pemahaman dan pengetahuan tentang sesuatu. Dalam pengertian ini figh dan fahm adalah sinonim. Pada mulanya digunakan orang Arab bagi seseorang yang ahli dalam mengawinkan unta, yang mampu membedakan unta betina yang sedang birahi dan unta yang sedang bunting. Pada zaman Pra Islam istilah Fiqh al-arab adalah gelar yang diberikan kepada al-Harits bin Kaladah yang dijuluki thalibal - arab.

Pada zamam Rasulullah - Nabi Muhammad SAW kata fiqh mencakup semua aspek dalam Islam yaitu theologis, politis, ekonomis dan hukum, karena Al Qur'an mempergunakan kata fiqh dalam pengertian memahami secara umum dilebih dari satu tempat. Dengan demikian, pada masa-masa awal Islam, istilah fiqh sebagaimana juga istilah $\mathrm{ilm}^{\prime}$ seringkali digunakan bagi pemahaman secara umum, meliputi prinsip-pinsip Islam maupun hukum-hukumnya (Ahmad Hasan ;1984:4-5) Fiqh pada masa Nabi (dan masa sahabat) diartikan sebagai ilmu (pengetahuan) yang tidak mudah diketahui umum, yang didapatkan dengan mempergunakan penyelidikan dan penelitian yang mendalam. (Hasbi Ash Shiddiqy:1985;30) Jadifiqh sama dengan ilmu yakni seluruh pengetahuan yang tidak mudah diketahui saat itu.

Setelah Rasul wafat, kaum muslimim dihadapkan pada persoalanpersoalan baru dan dipaksa untuk mempergunakan pertimbangan pribadi. Pada tahap ini istilah fiqh lalu sering digunakan dalam arti penggunaan kecerdasan. Jadi fiqh digunakan untuk pengetahuan yang dihasilkan dari penggunaan kecerdasan dan pendapat pribadi. Sedang kata ilm' $^{\prime}$ digunakan untuk pengetahuan yang diperoleh dari rangkaian perawi, karena pada saat itu orang sedang berusaha untuk mengumpulkan dan mencatat tradisi-tradisi yang sampai melalui rangkaian mata rantai periwayat.

Pada akhir abad I hijriyah, tatkala gerakan pengumpulan hadits dimulai, istilah ilmu dipergunakan 
dalam pengetahuan mengenai tradisi, yakni hadits dan atsar. Istilah fiqh diguna -kan secara ekslusif bagi pengetahuan yang dilandaskan pada penggunaan kecerdasan dan pertimbangan yang independen. Pada abad II hijriyah, pada masa mujtahid mulai membangun pola pemikiran mereka dan timbulnya madzhab , fiqh diartikan sebagai "hukum yang dipetik dari Kitabullah dan Sunnatur Rasul dengan jalan mempergunakan ijtihad (istinbath) yang sempurna memuncaknya, terhadap hukum-hukum yang mengenai amalan para mukallaf. Imam Abu Hanifah (Al Nukman ibn Tsabit, 700 767 M) memberikan batasan arti fiqh sebagai ilmu yang menerangkan segala hak dan kewajiban, yakni ilmu yang menerangkan segala yang diwajibkan, disunnatkan, dimakruhkan, diharamkan, dan dibolehkan. Imam Abu Hanifah masih memasukkan bidang ilmu lain yakni bidang kepercayaan kepada Khaliq dinamakan dengan "Fiqh Akbar". Definisi yang diberikan Abu Hanifah ini tidak berbeda maksudnya dengan ta'tif pada masa sahabat dan tabi'in, masuk di dalamnya urusan kepercayaan, urusan perangai budi pekerti, dll. Nampaknya hingga abad ke II hijriyah fiqh mencakup masalah theologis dan masalah hukum, kalam dan fiqh tidak dipisahkan sampai masa Al Ma'mun. Pada pertengahan abad ke II hijriyah definisi fiqh dipengaruhi oleh akiran-aliran golongan ahli ushul dan ahli fiqh. Beberapa ta'rif ahli ushul fiqh, di antaranya : As Sayyid Al Jurjani Al Hanafi mendefinisikan sebagai ilmu yang menerangkan hukum syara' yang amaliyah yang diambil dari dalil-dalilnya yang tafshily. Fiqh merupakan ilmu yang diistinbathkan dengan jalan ijtihad, oleh karena itu tidak boleh dinamakan Allah dengan faqih, karena tidak ada sesuatupun yang tersembunyi baginya. Pada saat ini fiqh sebagai ilmu diartikan sebagaimana diungkapkan oleh Abdul Wahhab Khalaf : ( Abdul Wahhab khallaf; 1985:11) "Ilmu fiqh ialah pengetahuan tentang hukum-hukum syari'at Islam mengenai perbuatan manusia yang diambil dari dalil-dalilnya secara detail. Atau koleksi-koleksi hukum syari'ah Islam tentang perbuatan manusia yang diambil berdasarkan dalil-dalinya secara detail". Secara bertahap rung lingkup istilah fiqh menyempit dan akhirnya hanya terbatas pada masalah hukum,, bahkan lebih sempit lagi yaitu pada literatur hukum yakni kitab-kitab fiqh.Ahmad Hasan 1984:6)

Hukum Islam mempunyai sifat universal, yang mengatur hubungan antara manusia dengan penciptanya, manusia dengan msyarakat dimana ia hidup dan manusia dengan alam lingkungannya, disegala waktu dan se- 
gala tempat. Hukum Islam mencakup segala aspek kehidupan manusia dan segala permasalahan hidup. Hukum Islam, dalam hal ini hukum amaliyahnya, terdiri atas dua cabang hukum yang utama, yakni hukum ibadah dan hukum muamalah. Ada juga ahli yang membaginya menjadi tiga bagian utama, yakni ibadat, uqubat, dan muamalah.Hukum ibadah adalah hukum yang mengatur hubungan manusia dengan Tuhannya, seperti shalat, puasa, zakat, haji, nadzar, sumpah dan ibadah-ibadah lain yang mempunyai arti mengatur hubungan manusia dengan Tuhannya.Hukum Muamalah, adalah hukum yang mengatur hubungan manusia dengan sesamanya, baik dilakukan secara perorangan, atau secara kelompok antara bangsa dan kelompok antara jama'ah, seperti akad, pembelanjaan, hukuman, jinayat, dll. Dalam hukum amaliyah tidak dibedakan (dengan tajam) antara hukum privat dengan hukum publik, dikarenakan pada hukum privat terdapat segi-segi publik dan sebaliknya. Jika kita analogikan dengan sistem hukum barat, maka susunan hukum muamalah dalam arti luas adalah sebagai berikut : (a) Hukum Privat (1) Munakahat, Hukum Perkawinan, mengatur segala sesuatu yang berhubungan dengan perkawinan, perceraian serta akibat hukumnya. (2)Wirasah, atau hukum fara'id, mengatur peralihan hak atas harta dari pewaris kepada ahli waris serta segala masalah yang berhubungan harta peninggalan (3)Muamalat dalam arti khusus, mengatur hak-hak atas benda dan perikatan (b) Hukum Publik (1)Jinayat, hukum pidana, yang mengatur mengenai perbuatan-perbuatan yang diancam dengan sanksi pidana. (2)Al Ahkam As Sulthaniyah, Hukum Tata Negara dan Hukum Administrasi (3)Siyar, Hukum Internasional, mengatur urusan perang dan damai, hubungan antar negara .

Hukum Islam adalah suatu sistem hukum yang spesifik, Hukum Islam mempunyai ciri-ciri khas yang membedahkannya dengan sistem hukum yang lain di dunia. Ciri-ciri khas Hukum Islam itu menurut Abdul Mutholib, adalah (1)Hukum Islam adalah hukum agama Islam; (2)Hukum Islam mengandung watak universal; (3)Hukum Islam dalam bidang ubudiyah halnya telah diatur sedemikian rupa dalam Al Qur'an dan As Sunnah; (4)Hukum Islam dalam bidang muamalah cocok insan kamil manusia, perasaan hukum, kesadaran hukum masyarakat dapat dikembangkan dan senantiasa tumbuh menurut kebutuhan dan pandangan hidup masyarakat dilandasi Al Qur'an dan As Sunnah. (Abdul Mutholib; tanpa tahun; 16)

Hukum Islam, didalamnya tercakup syari'ah dan fiqh Islam, ciri-ciri 
dari figh Islam menurut T. M. Hasbi Ash Shiddieqy adalah :(1)Fiqh Islam pada dasarnya kembali kepada Wahyu Illahi; (2)Figh Islam didorong pelaksanaan oleh aqiqah dan akhlaq; (3)Pembalasan yang diperoleh dari melaksanakan hukum-hukum fiqih adalah dunia akhirat; (4)Naz'ah (tabi'at kecenderung -an) fiqih Isalam adalah jama'ah; (5)Fiqh Islam menerima perkembangan sesuai dengan masa dan tempat; (6)Fiqh Islam tidak dipengaruhi oleh undangundang buatan manusia, baik Romawi, maupun yang lainnya; (7)Tujuannya adalah susunan hidup manusia yang khusus dan umum, mendatangkan kebahagiaan alam seluruhnya (T.M Hasbi Ash Shiddieqy:1985;152-156)

Hukum Islam dapat diterapkan dalam semua masa, untuk semua bangsa karena didalamnya terdapat cakupan yang begitu luas dan elastisitas dan daya tahan serta kepatuhan untuk segala jaman dan tempat. Hal ini dikarenakan Hukum Islam berdiri atas dua pokok dasar :(1)Hukum Islam memberikan prinsip umum disamping yang mendetail yang diberikan oleh sunnah sebagai tafsir dari Al Qur'an, dengan penetapan hal-hal yang seluas-luasnya dan membuka pintu yang selebarlebarnya buat kemajuan peradaban manusia. (Nasruddin Razak:72) Hukumhukum yang bersifat umum dalam Al
Qur'an dan As Sunnah mengandung prinsip-prinsip dan kaidah-kaidah kulliyah yang tidak berubah-ubah. Bidang ini menjadi lapangan kajian yang luas bagi para mutjahid dan terjadi perbedaan paham, perubahan, pergantian dan perbaikan. Bagian yang mempunyai kaidah-kaidah umum dan prinsip-prinsip yang bersifat keseluruhan inilah yang menjadi dasar dan pedoman yang tetap untuk menghadapi perkembangan masa. (T.M Hasbi Ash Shiddieqy 1381 H: 8) (2) Hukum Islam yang mengandung peraturan-peraturan yang terinci dalam hal-hal yang tidak terpengaruh oleh perkembangan masa, seperti dalam masalah muhrim (orang-orang yang haram untuk dikawin), ibadah, harta, warisan. (Nasruddin Razak: 72) Hukum yang terinci, jelas, langsung dapat ditetapkan pada kejadian atau kasus tertentu. (T.M Hasbi Ash Shiddieqy 1381H:10)

M. Hasbi Ash shiddieqy, secara lebih rinci membagi hukum Islam syari'at Islam - dalam empat bidang hukum, yakni : (T.M Hasbi Ash Shiddieqy 1381;10) (1)Yang tetap berlaku untuk setiap masa, tidak berubah-ubah, yang ditetapkan secara jelas dan tegas, tidak berarti bersifat statis, tetapi berkaitan dengan soal-soal yang tidak berubah-ubah dan terus hidup. Ada kalanya berkaitan dengan dasar kema- 
syarakatan, atau suatu prinsip undangundang yang tidak dapat dirubah dengan perubahan masa. (2)Hukum yang telah dinaskahkan tetapi nash-nash itu bisa diikwalkan, a dalam bidang ini berlaku ijtihad untuk mengakaitkan satu nash dengan nash yang lain, atau antara nash dengan kasus tertentu. (3)Hukum yang bersifat prinsip umum yang dapat kita masukkan kedalamnya beberapa masalah tertentu, maka bisa atau harus digunakan ijtihad untuk menerapkan prinsip umum itu. (4)Hukum yang tidak disinggung-singgung dalam syariat Islam, maka dalam bidang berlaku ijtihad mutlak.

Asas-asas yang dianut dalam Hukum Islam, secara singkat dapat dibedakan: (Nasrudin Razak 1972:254) (1)tidak memeberatkan (QS. II : 226) (2)sangat sedikit memuatn kewajiban secara terperinci yakni memerintah dan melarangnya (QS. Al Maidah : 101) (3) datang dengan prinsip graduasi (berangsur-angsur) bukan sekaligus disesuaikan dengan fitrah manusia dan jaman turunnya.

Dengan asas yang di anut diatas, maka prinsip-prinsip dasar dalam hukum Islam ialah mengakui hak manusia untuk memenuhi segala kebutuhan dan keinginan, menghasilkan manfaat untuk pribadi sebagaimana dikehendaki dengan catatan bahwa tidak boleh menyia-nyiakan hak orang lain. (T.M Hasbi Ash Shiddieqy 1973:41)

Hak-hak dan kewajiban setiap manusia menurut Hukuim Islam dapat dibagi dalam 4 kategori, yaitu: ( $A b u A^{\prime} l a$ Al Maududi: 1986:172-197) Hak-hak Allah SWT yang harus dipenuhi manusia; Hak-hak diri sendiri; Hak-hak manusia lain; Hak-hak makhluk lain dan benda-benda potensial yang dikaruniakan untuk kemanfaatan hidup manusia, Wajib bagi manusia untuk menerima dan mengikuti petunjuknya; Manusia harus taat dan patuh kepadaNya dengan jujur tanpa ragu; Manusia harus menyembahNya .Hak-hak ini harus didahulukan atas hak-hak yang lain, bahkan kadang-kadang penunaiannya dengan mengorbankan hak-hak yang dimiliki bagian lain. Hak-hak diri sendiri, manusia memiliki hak-hak tertentu dan merupakan kewajib -an dari manusia lain untuk menunaikannya dengan baik. Dengan hak inilah manusia dapat menjadi dirinya sendiri.

Hak-hak manusia lain, dalam pemenuhan hak pribadi tidak boleh merugikan hak-hak orang lain. Hukum Islam menerapkan keseimbangan antara hak-hak pribadi dengan hak-hak orang lain, serta hak-hak masyarakat agar tidak terjadi pertentangan antara keduanya dan harus ada kerja sama untuk mengembangkan hukum Allah. Hak-hak makhluk lain: Semua ciptaan Tuhan 
memiliki hak tertentu terhadap manusia, sehingga tidak bisa berbuat sesuka hati.

Hukum Islam secara garis besar mengenal dua macam sumber hukum, pertama sumber hukum yang bersifat "naqliy"dan sumber hukum yang bersifat “aqliy". Sumber hukum nagliy ialah Al Quran dan Assunnah, sedangkan sumber hukum aqliy ialah usaha menemukan hukum dengan mengutamakan olah pikir dengan beragam metodanya. Sumber hukum yang mengutamakan olah pikir ini terkait erat dengan istilah "fiqh" dan perkembangan penerapan Hukum Islam diberbagai kawasan dunia, tak terkecuali Indonesia. Sumber hukum ini pulalah yang juga berperan banyak dalam perbedaan pendapat diantara ahli hukum Islam menyangkut beragam aspek kehidupan dan menimbulkan madzab-madzab Hukum Islam. walaupun pada hakekatnya perbedaan madzab itu disebabkan perbedaan ijtijad - ushul figh: perbedaan teknis pemahaman -, kepentingan pribadi atau kelompok tertentu dalam aspek politik, serta perbedaan kualitas serta kapasitas intelektual pada masing-masing pendiri dan pengikutnya. (Mucthar Adam:1991:209) Hukum Islam dengan karakteristik yang khas mempunyai sumber-sumber hukum yang dapat dibedakan dalam (a)Sumber naqly, yakni sumber hukum dimana mujtahid tidak berperan dalam pembentukannya, bahkan mujtahid harus bersandar pada sumbangan, yang termasuk sumber hukum naqli dan As Sunnah. (b)Sumber Aqly, yakni suatu sumber hukum dimana seorang mujtahid dengan akalnya dapat berperan dalam pembentukannya seperti Qias, Istihsan, dan lain-lain

Disisi lain sumber hukum Islam dapat pula dibedakan dalam : (a)Sumber hukum Ashliyah, sumber hukum yang penggunaannya tidak tergantung pada sumber yang lain, yakni Al Quran dan As Sunnah. (b)Sumber hukum Taba'iyyah, sumber hukum yang penggunaannya bersandarkan pada ketentuan Al Qur'an dan As Sunnah, seperti Ijtima', Qias, Istishlah, dan lain-lain.

Kandungan hukum dalam Al Qur'an dan Hadist kadangkala bersifat prinsipil yang general (zanni) sehingga perlu interpretasi. Hadits kepada Muadz argumen pembolehan ijtihad sebagai sumber pengetahuan dan hukum dalam Islam. Qiyas, sebuah deduksi analogis, dapat dianggap sebagai salah satu manifestasi ijtihad. Ijtihad tetap didasarkan pada epistemologi yang utama, Al -Qur'an dan Sunnah:(Iggi H Achsiern: 2000:16-18)

Perkembangan Hukum Islam diantaranya juga terkait erat dengan masalah politik, karena persoalan yang mula-mula timbul dalam Islam memang 
politik yang berkisar pada masalah suksesi kepemimpinan dan masalah dosa besar capital sinners yang kemudian melebar kedalam masalah theologi dan hukum. (Harun Nasution: 1986:110) Kelompok-kelompok politik itu diantaranya eksis sampai saat ini dengan membawa pengaruh pada perkembangan hukum Islam seperti Ahlus-sunnah dengan empat madzab besarnya, Syiah dengan Fiqhus Syiahnya,(Mhmood Shehabi:1958:180-223) dan kelompok yang tinggal pengaruhnya saja dalam hukum Islam seperti aliran Iktizal. Joesoef Soeyb:1976:34)

Para ahli membagi perkembangan tasyri' Islami dalam beberapa periode, yakni: Periode Nabi, Periode Khulafaur Rasjidin, Periode Daulah Amawiyah, Periode Daulah Abbasiyah, Perriode Kemerosotan dan Periode Kebangkitan

Dalam sejarah agama Islam, tatkala Islam mulai berkembang di Madinah, agama, politik, hukum dan ekonomi serta aspek lainnya merupakan satu kesatuan yang tidak terpisahkan, ( $W$ Montgomery Watt, Muhammad: 1964: 92-95) Masa Khulafaur Rasjidin yang dimulai dari masa Abubakar Ash Shiddieqy memerintah sepeningalan nabi disebut dengan masa penetapan tiang-tiang ( da'a'im). Pada masa itu dimulailah pengumpulan Al Qur'an dalam satu mushhaf. Pada masa selanjutnya di bawah kepemimpinan Umar bin Khaththab seiring dengan perkembangan komunitas Islam, gebrakan banyak dilakukan seperti penyusunan administrasi pemerintahanan, pajak, kharaj, peradilan, perkantoran dan kalender. Umar bin Khaththab dikenal sebagai Imam al mujtahidin dengan beberapa hasil ijtihadnya. Umar juga dikenal sebagai penakluk, negarawan, pembaharu, pembawa hukum dan pemimpin spiritual sekaligus.(Syibli Nu'man:1981:8) PengumpulanAl Qur'an dalam satu mushhaf dengan qiraah (dialek) yang sama rampung dalam masa kepemimpinan Ustman bin Affan. Ali bin Abi Thalib sebagai pengganti Utsman bin Affan terkenal sebagai qadhi.

Pada masa Khulafaur Rasjidin terdapat beberapa fuqaha yang masyhur diantaranya : Abdullah Ibn Abbas, Zaid ibn Tsabit, Abdullah Ibn Umar di Madinah, Abdullah Ibn Mas'ud di Kufah, Abdullah Ibn Amr Ibn Ash di Mesir, Sayyidati Aisyah, Abu Musa al Asy'ari dan Mu'adz bin Jabal. (Rachmad Djatnika: 1991:4-5) Para ulama menulis bahwa dasar tasyri Islami pada masa Khulafaur Rasjidin ialah Al Qur'an, As Sunnah, Qiyas, dan Ijma'. Namun menurut Rachmat Djatnika dengan memeperhatikan hasil ijtihad Umar bin Khaththab ada dasar lain yakni $A l$ Istishlah atau Al Maslahat Mursalah dan 
Al Istihsan. Al Istishlah dipakai saat memutus kasus pencurian yang dilakukan buruh atas majikannya yang kikir, dan al Istihsan sdalam kasus Zakat untuk muallafatu qulubuhum. (Rachmad Djatnika: 1991:4)

Pada Ammawiyah yang dimulai tahun 41 H ( 661 M ) sampai kejatuhan Daulah Amawiyah di Damsyik pada tahun $132 \mathrm{H}$ (750M ), dikenal sebagai masa pembentukan fiqh Islami, yaitu ilmu furu' sya'riah dan hukum-hukumnya yang diambil dari dalil-dalil yang tafsili. Pada masa ini telah dimualailah penafsiran $\mathrm{Al}$ Qur'an, pengumpulan hadits, muculnya ilmu-ilmu Al Qur'an dan ilmu-ilmu hadits. Para fuqhaha meletakkan peraturan dasar yang diambil dari Al Qur'an, As Sunnah, Ijma' dan Qiyas, dan mereka terbagi dalam dua aliran besar, yakni Aliran Hijaz dan Aliran Iraq.

Aliran Hijaz, yang dikenal sebagai Madrasah Ahli Hadits karena berpegang teguh pada nash-nash As Sunnah. Dalam berpedapat mengikuti fiqh dua sahabat, Abdullkah Ibn Umar dan Zaid Ibn Tsabit, dan tabiin fuqaha tujuh yaitu Said Ibn Musayyab, Sulaiman Ibn Yasar, Urwah Ibn Zubair, Kharijah Ibn Zaid, Ubaidillah Ibn Utbah, Abybak Ibn Abdurrahman dan Qasim bin Muhamad.

Madrasah Iraq, atau terkenal sebagai kelompok al $R a^{\prime} y i$, karena terpengaruh masyarakat baru dan fuqahanya cenderung menggunakan qiyas. Dalam fiqh mereka mengikuti fiqh sahabat Abdullah Ibn Mas'ud dan tabiin Ibrahim an Nakkha'i, sedangkan dari kalangan Syiah dikenal Imam Jafar al Shadiq.

Pada masa Abbassiyah dikenal sebagai masa kemasan dengan perkembangan kebudayaan dan ilmu pengetahuan dengan munculnya gerakan penterjemahan beragam ilmu dari berbagai bahasa. Ilmu tafsir, Ilmu Hadits, ilmu fiqh, ilmu ushul fiqh dan ditulis pulalah kitab-kitab dalam hal furu' fiqh. Fuqaha Sunni terbagi dalam dua kelompok besar yaklni Ahli Ra'yi di Iraq yang ditokohi oleh Abu Hanifah dan Ahli Hadits di di Hijaz yang ditokohi Malik Ibnu Anas. Dalam perkembangannya muncul madzhab-madzhab Sunni dan Syiah yang besar seperti Hanafi, Maliki, Syafii dan Hanbali dari kalangan Sunni serta Imamiyah, Zaidiyah, dan Ismailliyah dari kalangan Syiah.

Para ilmuwan mulai membincangkan sesuatu secara mendalam. Pengkajian untuk membuat kaedah-kaedah untuk menetapkan hukum dengan mencarinya dari nash. Usaha membuat ilmu Ushul Fiqh untuk memperkuat hukum-hukum yang telah pernah dikutipkan dari para imam madzhab. Seperti apa yang telah dikutip para pengikut Abu hanifah dari Muwatha'. Perintis penyusunan penelitian dan kaedah-kaedah ilmu dalam 
suatu kumpulan tersendiri ialah Imam Muhammad bin Idris Asy Syafii dalam Ar Risalah. Upaya ini diikuti para ulama sesudahnya dengan upaya menyusun, menyempurnakan dan mensistematisasikannya. Menurut Ali Hasbullah pengkajian para ulama dalam Ushul Fiqh melalui tiga model, yakni : (Ali Hasbullah : tidak ada tahun :6-11) (1)Metode kaum Mutakkalimin atau kaum Syafii, melalui penelitian kaedah secara logis dan menetapkannya berdasarkan kekuatan alasan logika dan naql, tidak terikat kepada sekte tertentu dan tak terpengaruh oleh hukum furu' tertentu. Metode ini diikuti oleh sebagian besar ahli Ushul Syafiiyah seperti: Al Mustaafa karya Abu Hamid Al Ghozali, Al Mahsul karya Fakhruddin Muhammad bin Umar Ar Razi, Al Ihkam, Abul Hasan Al Amidi; (2)Metode Hanafiyah melalui penelitian kaedahkaedah didasarkan kutipan masalah masalah furu' para imam madzhab. Apabila kaedah bertentangan dengan masalah furu', maka kaedah tersebut diubah dan ditetapkan sesuai kehendak furu'. Penetapan pokok berdasarkan furu'nya dikutip dari imam-imam mereka. Kitab mereka lebih banyak memuat masalah furu', seperti Fakhrul Islam karya Ali bin Muhamad Al Bazdawi, Al Manar karya Abdullah bin Ahmad An Nasafi; (3)Metode campuran melalui penelitian kaedah-kaedah dan menjelaskan alasan-alasannya seperti: Tankihul Ushul karya Shadrusy Syariah, Jam-ul Jawani karya Tajuddin Al Subuki Al Syafii, At Tharir karya Al kamal bin Al Human Al Hanafi, Al Muwafaqat karya Abu Ishaq Al Syatibi, Irsyadul Fahul Ila Tahqiqil Haq min Ilmi Ushul karya Muhammad bin Ali Syauikani, Ushul Fiqh karya Syaikh Muhammad Hudlori.

Setelah masa keemasan Daulah Abbasuyah luluh lantak karena berbagai persoalan teritorial dan politis, ilmu fiqh mulai merosot perkembangnya. Para fuqaha hanya melakukan ijtihad fi al madzhab dengan menguraikan masalahmasalah yang telah diijtihadkan oleh imam madzhab, memberikan legitimasi dan justifikasi kepada hukum yang telah ada dan mentarjihkan dalil-dalil dari pendapat yang berbeda. Khalifahkhalifah Islam hanya menjadi pendukung madzhab yang sudah ada dan hakim mengikuti madzhab resmi dan tidak berijtihad. Pada permulaan abad keempat hijriyah dimaklumatkan di kalangan fuqaha sunni bahwa pintu ijtihad telah tertutup dan mulai berkembang bid'ah dan khurafat serta taqlid. (Rachmat Djatmika 1991 : 7)

Masa kemerosotan lambat laun mulai menghilang dengan muculnya gebrakan dari Ibn Taymiyah dan muridnya Ibnu Qayyim al Jauziyah yang 
mulai memerangi khurafat, bid'ah serta aktif menganjurkan pemahaman syariat dengan pengunakan akal atau dengan kata lain mempertajam ijtihad. (Rachmat Djatmika 1991 : 7)

Perkembangan Hukum Islam di Indonesia ditandai perdebatan seru yang melahirkan dua teori yakni teori Receptio in Complexu dan Teori Receptie. Pada awal abad ke 19, wacana pemikiran yang monopoli saat itu dikalangan orientalist ialah bahwa di Nusantara berlaku Hukum Islam, politik peradilan pun diperlakukan Hukum Islam untuk orang Islam. Masa itu oleh para ahli yang muncul kemudian dikenal dengan nama masa Receptio in Complexu Teori Receptio in Complexu ini menyatakan bahwa selama bukan sebaliknya dapat dibuktikan, hukum pribumi ikut agama, karena jika memeluk agama harus juga mengikuti hukum-hukum agama itu dengan setia. Jika suatu masyarakat memeluk suatu agama tertentu, maka hukum adat masyarakat itu adalah hukum agama yang dipeluknya. Jika ada hal-hal yang menyimpang, maka dianggap sebagai perkecualian atau penyimpangan dari hukum agama yang telah ditemukan dalam keseluruhan. Orang Islam di Hindia Belanda telah melakukan receptie Hukum Islam dalam keseluruhannya dan sebagai satu kesatuan receptio in complexu. Cikal bakal teori ini dari pendapat Solomon Keyzer dan didukung oleh LWC Van den Berg.

Theorie Receptio in Complexiu mendapat tantangan dari Christian Snouck Hurgronje, dalam buku hukumnya De Atjehers dan Het Gajoland, ia berpendapat bahwa yang berlaku bagi orang Islam di kedua daerah itu bukanlah Hukum Islam, tetapi hukum adat. Kedalam hukum adat itu memang telah masuk pengaruh Hukum Islam, tetapi pengaruh itu baru mempunyai kekuatan hukum kalau telah benar-benar diterima oleh hukum adat. Teori ini didukung oleh De la Porte,. Cornelis van Vollenhoven, Ter Haar Bzn, Piepers serta dilaksanakan dalam praktek oleh murid dan pengikutnya. (Abdul Mutholib 1984 :30) Landasan hukum dari Theori Receptie yang sudah dikembangkan secara sistematis pada permulaan abad XX ini dan dilaksanakan melalui Stb. 1931 No. 50 Yo. Stb. 1937 No. 116, adalah pasal 134 ayat 2 Wet op de Staatsinrihchting van Ned. Indie (I.S) yang berbunyi : Evenwel staan de burgerlijke rechtzaken tusschen Mohammedanen, indien hun adatrecht dat medebrengt, tekennisneming van den godsdienstigen rechter, voor zoover niet bij ordonnantie anders is bepaald. Yang jelasnya jika terjadi perkara perdata antara sesama orang Islam, maka akan diselesaikan oleh hakim agama Islam jika telah diterima 
oleh hukum adat mereka sejauh tidak ditentukan oleh lain ordonnantie.(Mohammad Daud Ali ) Teori ini juga mendapat tantangan dari beberapa pemikir Hukum Islam, yang berpendapat bahwa teori ini mempunyai maksud politik untuk mematahkan perlawanan bangsa Indonesia terhadap kekuasaan pemerintah kolonial yang dijiwai oleh Hukum Islam. (Mohammad Daud Ali ; 17)

Teori muncul kepurmukaan bersamaan dengan suasana politik saat itu, termasuk politik hukum mulai mempersoalkan rumusan pasal 75 dan 109 R.R Stb 1855 No. 2. Sebagai implementasi dari anjuran para orientalist yang dominan saat itu maka diadakan perubahan peraturan perundangan di Hindia Belanda. Orientalist yang dominan saat sedang giat-giatnya melakukan studi hukum adat.

Hukum adat saat itu diartikan sebagai "Dat samenstel van voor inlanders (.....) geldende gedragsregels, die anderzijds sanctie hebben (daarom "recht) en anderzijds in ongecodificeerden staat verkeeren (daarom 'adat)." (= keseluruhan peraturan yang berlaku buat orang Indonesia asli, yang pada satu pihak mempunyai sanksi (oleh karena itu 'hukum) dan pihak lain berada dalam keadaan tidak dikodifikasi (oleh karena itu : adat) ( Van Vollenhoven: 1918:14)
Teori Receptie Exit merupakan bentuk kritik pakar Hukum Adat, Hazairin teori receptie exit maksudnya adalah bahwa teori receptie harus keluar dari teori hukum nasional Indonesia karena bertentangan dengan UUD 1945 serta bertentangan dengan Al-Quran dan Sunnah Rasul. Pada tahun 1950 dalam Konprensi Departemen Kehakiman di Salatiga Hazairin, mengarahkan suatu analisa dan pandangan agar Hukum Islam itu berlaku di Indonesia, tidak berdasar pada hukum adat. Berlakunya Hukum Islam untuk orang Indonesia supaya disandarkan pada penunjukan peraturan perundang-undangan sendiri. Sama seperti hukum adat selama ini yang dasar memperlakukan hukum adat itu sendiri ialah berdasarkan sokongan peraturan perundang-undangan.

Dalam bukuinya tentang Hukum Kekeluargaan Nasional, Hazairin berpandangan bahwa teori recepsi Christian Snouck Hurgronje itu sebagai teori iblis. Ungkapan Hazairin ditujukan pula kepada tidak sahnya lagi pasal 134 (2) IS, dijadikan dasar pengaturan hukum di Indonesia. Kritik lain diantaranya dilakukan Sayuti Thalib melalui teori yang disebutnya Teori Receptio a Contra-rio. Guna mendukung teorinya, beliau mengemukakan fakta di beberapa daerah yang dianggap sangat kuat adatnya di Indonesia yang terlihat kecenderungan 
agar theorie receptie C. Snouck Hergronje itu dibalik. Di Aceh, masyarakat menghendaki agar soal-soal perkawinan dan mengenai harta termasuk kewarisan diatur menurut Hukum Islam. Hukum adat atau upacara adat baru berlaku kalau tidak bertentangan dengan Hukum Islam.

Demikian pula di Minangkabau, daerah yang kedudukan adatnya sangat kuat terdapat ketentuan yang tegas-tegas bahwa adat itu baru dapat berlaku kalau bersandar kepada agama, sebagaimana diungkapkan dalam pepatah dan petitih, diantaranya : - Adat bersendi syara', Syara' bersendi kitabullah, Syara' mengata, adat memakai

Yang tertinggi kedudukannya dalam hukum mereka adalah Kitabullah yakni Al-Qur'an, sebagai sumber hukum dan upacara dan segala-galanya. Agama Islam merupakan tempat bersandarnya adat yang sangat kuat dalam masyarakat Minangkabau. Hal serupa terdapat di daerah Riau, Jambi, Palembang, Bengkulu dan Lampung. Lebih lanjut Sayuti Thalib berpendapat bahwa " Sekarang yang ada dalam hubungan Hukum Adat dan Hukum Islam ialah Receptie a Contrario=hukum adat baru berlaku kalau tidak bertentangan dengan Hukum Islam. Dengan demikian dalam jiwa masyarakat, telah menang jiwa Pembukaan dan Pasal 29 Undang- Undang
Dasar 1945 dan telah mengalahkan pasal 134 ayat (2)Indische Staatsregeling itu".

M. Daud Ali berpendapat bahwa di Indonesia Hukum Islam ada yang berlaku secara normatif dan ada pula yang berlaku secara formal yuridis. Hukum Islam yang berlaku secara normatif adalah bagian dari Hukum Islam yang mempunyai sanksi kemsyarakatan apabila dilanggar. Pelaksanaan dan kuat tidaknya sanksi kemasyarakatan itu tergantung pada kuat lemahnya kesadaran umat Islam akan norma-norma hukum yang berifat normatif itu. Hukum Islam yang berlaku secara normatif itu diantaranya: sholat dan puasa. Hampir semua bagian Hukum Islam yang mengatur hubungan menusia dengan Tuhan, bersifat normatif. Hukum Islam yang berlaku secara formal yuridis adalah bagian Hukum Islam yang menjadi bagian hukum positif berdasarkan atau karena ditunjuk oleh peraturan perundang-undangan seprti perkawinan, wakaf, dan sebagainya.

Era Globalisasi disemarakkan kehadiran lembaga-lembaga perekonomian yang berpacu untuk mengumpulkan keuntungan sebanyak mungkin bagi para pelaksananya. Di arena persaingan yang semakin ketat itu muncul lembaga-lembaga perekonomian yang berlatar belakang keagamaan, walaupun kemudian lebih dimotivasi keuntungan 
bisnis semata. Lembaga perekonomian yang bernuansa keagamaan itu diantarnya beroperasi berdasarkan prinsip syariah Islam. Prinsip syariah mengedepan seiring dengan pesatnya pengkajian Islamic Studies terkhusus ekonomi Islam di dunia International.

Doktrin ekonomi Islam muncul pada abab XX dimaksudkan untuk membangun sistem ekonoimi yang sesuai dengan wahyu (Islamic Scepture) dan tradisi yang melingkupinya. Diawali pada tahun 1940an dan baru pada tiga dekade kemudian konsep itu muncul kepermukaan di berbagai negara. Sekarang lebih dari 60 negara membuka bank Islam dengan menawarkan sistem free interest yang disebut sebagai alternatif dari bank dengan sistem bunga. Perekembangan doktrin ini bermula dari benua India dan didukung momen penting dalam kasus booming minyak di tahun 1970an. Pada tahun 1975 didirikan Islamic Development Bank dengan maksud untuk memberikan bantuan bagi perkembangan negara berkembang muslim dengan pinjaman tanpa bunga. Kemudian dimulailah perbaikan infra struktur ekonomi Islam, sekolah-sekolah bisnis Islam didirikan di sejumlah negara, begitu pula dengan penerbitan jurnal ekonomi Islam dan pertemuan reguler lembaga donor. Sejak itu ekonomi Islam dinampakkan sebagai disiplin akademis. Riset digalakkan tatkala muncul masalah berbagai model aplikasi dari ekonomi Islam termasuk sisrtem retribusi dan bank Islam menjadi diskursus baru. (Timur Kuran: 1997: 337 -338) Beberapa ahli hukum ekonomi dan hukum Islam kemudian merumuskan konsep dasar bank yang berdasarkan pada aturan syariat Islam. Sejak tahun 1970-an, perbankan syariah telah muncul sebagai suatu kenyataan yang baru dalam bisnis keuangan Internasional.(Sultan Reny Sjahdeini: 2002:8)

Di bidang ekonomi perkembang -an pesat Hukum Islam ialah didalam aplikasi hasil formulasi doktrin ekonomi Islam dalam konteks modern (Frank $E$ Vogel and Samuel Hayes: 129-178), yang diaplikasikan dalam bidang perbankan, asuransi, arbitrase, pengadaian, Finance, reksadana serta general trade..

Bank syariah sebagai lembaga intermediasi melakukan kegiatannya berdasarkan beberapa prinsip yang dikenal dalam Hukum Islam. Bank syariah terkadang berkedudukan sebagai mudharib (pengelola dana), syarik (peserta dalam joint venture) dan terkadang pula sebagai penjual (dalam kontrak murabahah) dan penjual jasa serta beberapa kedudukan hukum lain secara teoritis walaupun belum bisa diimplementasikan. Bank syariah sebagai bagian dari sistem perbankan 
nasional, perbankan syariah tunduk pada aturan umum tentang perbankan dalam hukum perbankan nasional. Dalam prakteknya terkadang perbankan syariah memakai aturan-aturan yang sudah lazim dipakai dalam dunia perbankan baik produk hukum nasional maupun lembaga hukum barat yang terus dipakai dalam praktek.

\section{PENUTUP}

Hukum Islam secara garis besar mengenal dua macam sumber hokum, pertama sumber hukum yang bersifat "naqliy"dan sumber hukum yang bersifat "aqliy". Sumber hukum nagliy ialah Al Quran dan Assunnah,sedangkan sumber hukum aqliy ialah usaha menemukan hukum dengan mengutamakan olah pikir dengan beragam metodanya. Sumber hukum yang mengutamakan olah piker ini terkait erat dengan istilah "fiqh"dan perkembangan penerap -an Hukum Islam diberbagai kawsan dunia, tak terkecuali Indonesia. Sumber hukum ini pulalah yang juga berperan banyak dalam perbedaan pendapat di antara ahli hukum Islam menyangkut beragam aspek kehidupan dan menimbulkan madzab-madzab Hukum Islam. Pada hakekatnya perbedaan madzab itu disebabkan perbedaan ijtijad-ushul figh: perbedaan teknis pemahaman, kepenting -an pribadi atau kelompok tertentu dalam aspek politik, serta perbedaan kualitas serta kapasitas intelektual pada masingmasing pendiri dan pengikutnya. Perbedaan madzab-madzab Hukum Islam, tidaklah madzab-madzab itu keluar dari Syariat Islam selama madzab-madzab itu merujuk Al-Qur'an dan As-Sunnah dalam Ushul Fiqhnya. Perbedaan pendapat dalam merumuskan hukum disebabkan beberapa alasan. Alasan tersebut dapat disimpulkan pada satu alasan utama yang dapat menampung alasan lainnya yaitu perbedaan mereka dalam memahami dalil syara', Al Qur'an maupun Hadits. Di samping itu diantara ulama telah ada yang punya pendapat sebelum menelaah dalil dan pencarian serta penelahan dalil kemudian hanya dalam rangka usaha menguatkan pendapatnya. Situasinya menjadi terbalik syariah yang pada dasarnya menjadi sumber dan penuntun dalam merumuskan hukum, menjadi berfungsi sebagai penguat pendapat yang muncul. Kondisi semacam ini muncul karena pengaruh politis yang dianutnya atau karena adat istiadat yang mereka anggap dapat disuaikan dengan hukum Islam. Hukum Islam diantaranya memuat beberapa ketentuan yang merombak beberapa ketentuan tradisi pra Islam pada masyarakat Arab Jahiliyah-asathir al awwalinmitologi pra Islam pasa masyarakat Arab Kuno dan tradisi sekitarnya 


\section{DAFTAR PUSTAKA}

A Fyzee, (1955). Outlines of Muhammedan Law, Oxford University Press, London

A Mukti Ali, (1970). Kuliah Agama Islam di Sekolah Staf dan Komando Angkatan Udara di Lembang, Nida, Yogyakarta

A Azis Mashuri, Kuliah Ushul Fiqh, Unhasy, Jombang

Abdul Mutholib, (1984). Kedudukan Hukum Islam Dewasa Ini di Indonesia, Bina Ilmu, Surabaya

Abdul Qahir Al-Bagdadi, (1973). Al Farq Bayr Al Firaq, Dsr Al-Ataq Al-Jaddah, Beirut,

Abdul Wahhab Khallaf, Ilmu Ushulil Fiqh, Al Majlisl A'al Al Indonesia lil Dakwatil Islamiyah,

Abdul Wahhab Khallaf, (1985). KaidahKaidah Hukum Islam, Vol.I, terjemahan Tolchah Mansoer dkk, Risalah, Bandung

Abu A'la Al Maududi, (1986). Dasardasar Aqidah Islam, terjemahan, Elwin Siregar, Media da'wah, Jakarta

Ahmad Hasan, (1984). Pintu Ijtihad Sebelum Tertutup, terjemahan Agah Garnadi, Pustaka, bandung

Ahmad Rofiq, (1998). Hukum Islam di Indonesia, RajaGrafindo Persada, Jakarta

Ali hasbullah, Ushulut vTasyri" al
Islamiy, terjemahan Muhammad Thalib, Fak Syariah UII, Yogyakarta

Charles Himawan, (1995) "Menerapkan Temuan Ilmiah Untuk Mengikis Kemiskinan Peran Hukum Dalam Pembangunan Ekonomi, Hukum dan Pembangunan_, No5 Tahun XXV

Edgar Bodenheimer, John Bilyev Odleley, Jean C. Love, (1988). An Introduction to the AngloAmerican Legal System, Reading and Cases, 2 nd ed, West Publishing,Minn

E d w a r d S a i d, ( ( $\left.\begin{array}{llll}1 & 9 & 7 & 9\end{array}\right)$. Orientalisme, Vartage Books, Random House, N.Y

Frank E. Vogel and Samuel L. Hayes, III, Islamie Law and Finance: Religion, Risk and Retevasi, Kluwen Law International Nederland, 500 P, Chapter G.P

H.A.R. Gibb, (1955). Mohammedanisn, The New American Library, New York

Harun Nasution, (1986). Theology Isalam, Aliran-aliran Sejarah Analisa Perbandingan, UI Press, Jakarta

Hazairin, (1990). Hukum Kewarisan Bilateral Menurut Qur'an dan Hadith, Tintamas, Jakarta,

Humaidi Tatapangarsa, (1979). Pengantar Kuliah Akhlak, Bina Ilmu, Surabaya

Iggi H. Achsiern, (2000). Investasi 
Syariah di Pasar Modal, Gramedia, Jakarta

JND Anderson, (1976). Law Reform in the Muslim World, Athlone, London

Joesoef Soeyb, (1982). Peranan Aliran Iktizal Dalam Perkembangan Aliran Pikiran Islam, Pustaka Al Husna, Jakarta

Mahmood Shehabi, (1958). "SHIA", dalam Kenneth W. Morgan, IslamThe Straight Path, the Ronald Press

Mahmud Hambali Zaqzaq, (1984). Orientalisme dan Latar Belakang Penulisannya,terjemahan Luthfie Abdullah Ismail, Al Muslimin, Bangil

Mardjono Reksodipoetro, (1995). "Pembinaan Pendidikan Tinggi Hukum Dalam Pembangunan Jangka Panjang Kedua (PJPT II), Hukum dan Pembangunan, No.3 tahun XXV

Mohammad Aud Ali, (1984). Kedudukan Hukum Isalam Dalam Sistem Hukum Indonesia, Risalah, Jakarta

Muchtar Adam, (1991) "Perbandingan Madzab Dalam Is la m Permasalahannya", Dalam Tjun Suryaman (ed), Hukum Islam di Indonesia, Pemikiran dan Praktek, Remaja Posdakarya, Bandung

Muhammad Muslehuddin, (1999). Menggugat Asuranasi Modern : Mengajukan Suatu Alternatif baru dalam Perspektif Hukum Islam, terjemahan Burhan Wirasubrata, Lentera, Jakarta

Nasruddin Razak, (1972). Dienul Islam, Almaarif, Bandung

Rachmat Djatnika, (1991). "Perkembangan Ilmu Fiqh di Dunia Islam", dalam Hukum Islam di Indonesia, Perkembamngan dan pembentukan., Reamaja Rosdakarya, Bandung

Rene David and Jhon C. Brierly, (1978). Mayor_Legal System in the World Today, Steven \& Sons, London

Sahilun A. Nasir, (1980). Ilmu Kalam, Pengertian, Sejarah dan Perkembangannya, Bina Ilmu, Surabaya

Satria Effenndi M. Zein, et.al. (1994). Arbitrase Islam di Indonesia, BAMUI-BMI, Jakarta

Sayyid Sabiq, (1986). Aqidah Islam, terjemahan Moh. Abdai Rathony, Diponegoro, Bandung

Steven Vago, (1994). Law and Society, Prentice Hall, N.Y.

Sudirman Tebba, (1993) Perkembangan Mutakhiri Hukum Islam di Asia Tenggara: Studi Kasus Hukum Keluarga dan Pengkodikasiannya, Cet. I, Mizan, Bandung

Sultan Reny Sjahdeini, (2002) “ Perbankan Syariah Suatu Alternatif Kebutuhan Pembiayaan Masyarakat," Jurnal Hukum Bisnis, vol 20

Syaidus Syahar, (1986). Asas-asas 
Hukum Islam, Alumni, Bandung

Syaikh Mahmoud Syaltout, (1967).

Islam sebagai Aqidah dan Syariah, terjemahan Bustani A.Gani dan B. Hamdany Ali, Bulan Bintang, Jakarta

Syibli Nu'man, (1981). Al Farooq, Life of Omar The Great, Secon Caliph of Islam, terjemahan Karsidjo Djojosuwarno, Pustaka, Bandung

T.M. Hasbi Ash-Shiddieqy, (1973) Fungsi Aqidah Dalam Kehidupan Manusia dan Perpautannya dengan Ibadah, IAIN Sunan Kalijaga, Yogyakarta

T.M. Hasbi Ash-Shiddieqy, (1381 H). Syariat Islam Menjawab tantangan Zaman, Pidato Dies Natalis IAIN Sunan Kalijaga Yogyakarta

T.M.Hasbi Ash Shiddieqy, (1985). Pengantar Ilmu Fiqh, Bulan Bintang

Timur Kuran, The Genesis of Islamic Ekonomics: A Chapter in the Politics of Muslim Identity, Social Research, Vol. 64, Summer, 1997

W. Montgomery Watt, Muhammad : Prophet and Stateman , (1964). Oxford University Press, Oxford 